\title{
Preservation of Ready to Serve Blended Carrot and Kinnow (Mandarin) Drink by Ginger Extract
}

Naeem Ullah*, Ihsan Mabood Qazi, Shaista Masroor, Iftikhar Ali, Abbas Khan, Majid Khan and Afsheena Gillani

Department of Food Science and Technology, The University of Agriculture, Peshawar, Pakistan

\begin{abstract}
This study explore the effect of lemon and ginger extract on carrot and kinnow blended ready to serve (RTS) drinks during three months refrigeration temperature storage. The treatments were CKG0,CKG1,CKG2,CKG3,CKG4,CKG5 and CKG6 having 0.5 liter carrot juice, 0.5 liter kinnow juice, $1 \mathrm{~g} / \mathrm{kg}$ CMC, $1 \mathrm{~kg}$ sugar, 5 liter water with variations in lemon and ginger extract in different levels. All the RTS samples were evaluated for total solids, moisture, ash, $\mathrm{pH}$, reducing sugar, ascorbic acid, non-reducing sugar, titratble acidy, total soluble solids, total microbial count and sensory attribute (taste, colour, flavor and overall acceptability). Statistical analysis revealed that treatment as well as storage had significant $(p<0.05)$ effect on physicochemical and sensory properties. Results showed that $\mathrm{pH}$ and sugar acid ration of the treated samples was decrease during storage. While TSS, acidity, reducing and non-reducing sugar and vitamin $\mathrm{C}$ increased were observed during storage. Generally this is observed from the results that CKG6 sample was more acceptable than RTS of the samples on the basis of physiochemically. On the other hand, in terms of taste and flavor CKG6 sample was highly acceptable, sample CKG3 had good color and over all acceptability. However, RTS drinks prepared from with carrot and kinnow blends (CKG6) is recommended for commercial use and for production on large scale.
\end{abstract}

Keywords: Ginger; Ready to serve beverage; Physico-chemical properties; Sensory properties; Microbial analysis

\section{Introduction}

Carrot (Daucus carota) is winter vegetable, production wise carrot ranked in third position. In Pakistan, carrot is produced 192000 metric tons annually in an area of 11000 hectars. Carrots are one of the rich sources of moisture, protein, carbohydrate, crude fiber and minerals.

Kinnow Mandarin (Citrus reticulate) is a citrus fruits having sweet taste, bright colour and appearance grown. Mandarin is an important fruit and contain vitamins mostly vitamin $C$, vitamin $A$, minerals such as iron, phosphorus and calcium and citric acid [1]. Citrus fruit juice contains highly ascorbic acid 60 to $70 \mathrm{mg}$ which is good for body health. It is also contains antioxidants (vitamin C) and flavonoids which has healthier effect than dietary benefits.

Ginger has been widely used as spice and flavoring agents in foods and beverages. Ginger has been used as a spice for over 2000 years. The composition of raw ginger is water, Protein, carbohydrate, fiber and Ash. Ginger is used to obtain different extracts. It is a good source of polyphenol compounds and composed as other roots. Ginger used as an antioxidants and their extracts is used as anti tumor effects which caused due to Epstein-Barr virus or applied against cancer.

This is quite challenging to prepare RTS beverage without the addition of chemical preservatives. The aim of study is to develop an acceptable quality RTS by blending carrot, kinnow, lemon juices and with addition of ginger extract to determine the most suitable concentration of lemon juice and ginger extract for the commercial preparation of RTS beverage with longer shelf life. This study also aimed to formulate carrot and kinnow blend RTS beverage to take advantage of both fruits which are nutritionally diverse and have synergetic effect when consume simultaneously. Citrus fruits are considered to be the rich source of ascorbic acid, pectin, carotenes, citric acid, and minerals like calcium and phosphorous. Carrots contain high levels of carbohydrates and $B$-carotene. Keeping in view the nutritional and medicinal importance of ginger, the treatments has been formulated with a unique formulation.

\section{Objectives}

- To produce value added ready to serve beverage from various blends of carrot, kinnow and lemon.

- To develop suitable combination of carrot, kinnow and lemon RTS juice.

- To study the effect of ginger extract as an alternate of chemical preservative in prepared RTS juice.

- To study physicochemical and organoleptic properties of blended carrot and kinnow RTS juice.

\section{Methods and Materials}

This study was carried out in Agriculture research institute (ARI), Tarnab and Department of Food Science and Technology laboratories. Carrot, kinnow, lemon and ginger were purchased from the local market at Tarnab, Peshawar and brought to the laboratory of ARI Tarnab, Peshawar for preparation of ready to serve drinks.

\section{Preparation of ready to serve drink (RTS)}

The carrots were peeled and then heated in water having temperature up to $90-95^{\circ} \mathrm{C}$ for $25-30$ minutes in order to soften the pulp. The boiled carrot was put in the pulping machine (Pulper juicing machine made in Jiangsu China) to get the pulp. The pulp was passed through muslin cloth in order to get clear juice. The kinnow were cut into two equal halves and the juice was extracted through juice

*Corresonding author: Naeem Ullah, Department of Food Science and Technology, The University of Agriculture, Peshawar, Pakistan, E-mail: naeemullahswati@gmail.com

Received February 21, 2015; Accepted March 14, 2015; Published March 21 2015

Citation: Ullah N, Qazi IM, Masroor S, Ali I, Khan A, et al. (2015) Preservation of Ready to Serve Blended Carrot and Kinnow (Mandarin) Drink by Ginger Extract. J Food Process Technol 6: 438. doi:10.4172/2157-7110.1000438

Copyright: (c) 2015 Ullah N, et al. This is an open-access article distributed under the terms of the Creative Commons Attribution License, which permits unrestricted use, distribution, and reproduction in any medium, provided the original author and source are credited. 
Citation: Ullah N, Qazi IM, Masroor S, Ali I, Khan A, et al. (2015) Preservation of Ready to Serve Blended Carrot and Kinnow (Mandarin) Drink by Ginger Extract. J Food Process Technol 6: 438. doi:10.4172/2157-7110.1000438

Page 2 of 6

extractor. Then juice was passed through muslin cloth to separate juice from pulp. The lemon were cut into two equal halves and the juice was extracted manually and filtered through muslin cloth to remove debris and unwanted materials. Ginger were peeled and cut into small pieces then crushed and juice was extracted with the help of blender and filtered from muslin cloth to separate juice from pulp. Ready to serve drinks were prepared in three replications from carrot, kinnow and lemon juice. All the juices were mixed in water along with other ingredients namely; sugar, CMC (used as a viscosity modifier or thickener, dissolves rapidly in cold or hot water and stabilize emulsions in various products these properties and functions make it suitable for use in a broad range of applications in the food) and ginger extract (Table 1).

\section{Physicochemical analysis}

$\mathrm{pH}$, Total Soluble Solids, Total Titratble Acidity, Sugar acid ratio, Ascorbic acid Reducing and Non reducing sugars were determined by the standard method of AOAC [2].

\section{Sensory evaluation}

The sensory evaluation for taste, flavor, color and overall acceptability should be conducted by using nine hedonic [3].

\section{Microbial study}

The sample will be analyzed for the total fungal by total plate count (TPC) method as described by Kumar et al. [4].

\section{Statistical analysis}

Statistically the data was analyzed by using CRD with two factors (treatment and storage) and mean were separated by LSD test at $0.05 \%$ significant level [5].

\section{Result and Discussion}

\section{pH}

Table 2 shows the impact of storage and treatments on $\mathrm{pH}$ of value added ready to serve drinks prepared from blend of carrot, kinniow and ginger. Statistically both storage and treatments had significant ( $\mathrm{p}$ $<0.05$ ) effect on $\mathrm{pH}$ of ready to serve drinks. This was observed from the data that $\mathrm{pH}$ of the treated sample were in range of $3.5\left(\mathrm{CKG}_{6}\right)$ to $3.91\left(\mathrm{CKG}_{4}\right)$ on zero day of storage, which decrease upto3.37 $\left(\mathrm{CKG}_{6}\right)$ $3.76\left(\mathrm{CKG}_{4}\right)$ after 90 days of storage. Highest mean $\mathrm{pH}(3.83)$ was observed for treatment $\mathrm{CKG}_{4}$, while the lowest mean $\mathrm{pH}$ (3.56) was observed for control sample. In term of storage maximum mean $\mathrm{pH}$ (3.69) was noticed at zero day of storage while minimum mean $\mathrm{pH}$ (3.54) was recorded after 90 days of storage prepared RTS. However higher $\mathrm{pH}$ decrease was found in sample $\mathrm{CGG}_{0}(4.44 \%)$ while lower $\mathrm{pH}$ was observed in $\mathrm{CKG}_{6}$ (3.71\%). The degradation of reducing sugar and formation of acidic compounds from it causes a decline in $\mathrm{pH}$ ( $\mathrm{Zia}$ ).

\begin{tabular}{|l|c|c|c|c|c|c|c|}
\hline Treatments & $\begin{array}{c}\text { Carrot } \\
\text { juice }\end{array}$ & $\begin{array}{c}\text { Kinnow } \\
\text { juice }\end{array}$ & CMC & Sugar & Water & $\begin{array}{c}\text { Ginger } \\
\text { extract }\end{array}$ & $\begin{array}{c}\text { Lemon } \\
\text { juice }\end{array}$ \\
\hline CKG0(control) & $0.5 \mathrm{~L}$ & $0.5 \mathrm{~L}$ & $1 \mathrm{~g} / \mathrm{kg}$ & $1 \mathrm{~kg}$ & $5 \mathrm{~L}$ & & \\
\hline CKG1 & $0.5 \mathrm{~L}$ & $0.5 \mathrm{~L}$ & $1 \mathrm{~g} / \mathrm{kg}$ & $1 \mathrm{~kg}$ & $5 \mathrm{~L}$ & & $50 \mathrm{ml}$ \\
\hline CKG2 & $0.5 \mathrm{~L}$ & $0.5 \mathrm{~L}$ & $1 \mathrm{~g} / \mathrm{kg}$ & $1 \mathrm{~kg}$ & $5 \mathrm{~L}$ & $10 \mathrm{ml}$ & \\
\hline CKG3 & $0.5 \mathrm{~L}$ & $0.5 \mathrm{~L}$ & $1 \mathrm{~g} / \mathrm{kg}$ & $1 \mathrm{~kg}$ & $5 \mathrm{~L}$ & $10 \mathrm{ml}$ & $50 \mathrm{ml}$ \\
\hline CKG4 & $0.5 \mathrm{~L}$ & $0.5 \mathrm{~L}$ & $1 \mathrm{~g} / \mathrm{kg}$ & $1 \mathrm{~kg}$ & $5 \mathrm{~L}$ & & $80 \mathrm{ml}$ \\
\hline CKG5 & $0.5 \mathrm{~L}$ & $0.5 \mathrm{~L}$ & $1 \mathrm{~g} / \mathrm{kg}$ & $1 \mathrm{~kg}$ & $5 \mathrm{~L}$ & $20 \mathrm{ml}$ & \\
\hline CKG6 & $0.5 \mathrm{~L}$ & $0.5 \mathrm{~L}$ & $1 \mathrm{~g} / \mathrm{kg}$ & $1 \mathrm{~kg}$ & $5 \mathrm{~L}$ & $20 \mathrm{ml}$ & $80 \mathrm{ml}$ \\
\hline
\end{tabular}

Table 1: Proposes study plan, shows the ratios of different ingredients for ready to serve drinks.

\begin{tabular}{|l|c|c|c|c|c|c|}
\hline \multirow{2}{*}{ Treatment } & \multicolumn{4}{|c|}{ Storage Intervals } & \multirow{2}{*}{ \% decrease } & Means \\
\cline { 2 - 5 } & 0 & 30 & 60 & 90 & & \\
\hline $\mathrm{CKG}_{0}$ & 3.6 & 3.55 & 3.49 & 3.44 & 4.44 & $3.52 \mathrm{f}$ \\
\hline $\mathrm{CKG}_{1}$ & 3.8 & 3.75 & 3.69 & 3.65 & 3.95 & $3.72 \mathrm{~b}$ \\
\hline $\mathrm{CKG}_{2}$ & 3.7 & 3.65 & 3.6 & 3.54 & 4.32 & $3.62 \mathrm{~d}$ \\
\hline $\mathrm{CKG}_{3}$ & 3.71 & 3.65 & 3.6 & 3.57 & 3.77 & $3.63 \mathrm{c}$ \\
\hline $\mathrm{CKG}_{4}$ & 3.91 & 3.86 & 3.8 & 3.76 & 3.84 & $3.83 \mathrm{a}$ \\
\hline $\mathrm{CKG}_{5}$ & 3.63 & 3.58 & 3.53 & 3.48 & 4.13 & $3.56 \mathrm{e}$ \\
\hline $\mathrm{CKG}_{6}$ & 3.5 & 3.46 & 3.41 & 3.37 & 3.71 & $3.44 \mathrm{~g}$ \\
\hline Means & $3.69 \mathrm{a}$ & $3.64 \mathrm{~b}$ & $3.59 \mathrm{c}$ & $3.54 \mathrm{~d}$ & & \\
\hline
\end{tabular}

Figures having different small letters shows significant difference $(p<0.05)$

Table 2: Effect of ginger extract on the $\mathrm{pH}$ of carrot and kinnow ready to serve beverage.

\begin{tabular}{|c|c|c|c|c|c|c|}
\hline \multirow[t]{2}{*}{ Treatment } & \multicolumn{4}{|c|}{ Storage Intervals } & \multirow[t]{2}{*}{$\%$ decrease } & \multirow[t]{2}{*}{ Means } \\
\hline & 0 & 30 & 60 & 90 & & \\
\hline $\mathrm{CKG}_{0}$ & 15.5 & 15.9 & 16.4 & 16.9 & 8.28 & $16.17 a$ \\
\hline $\mathrm{CKG}_{1}$ & 15.5 & 15.9 & 16.4 & 16.8 & 7.74 & $16.15 a$ \\
\hline $\mathrm{CKG}_{2}$ & 15.6 & 16 & 16.5 & 17 & 8.24 & $16.27 a$ \\
\hline $\mathrm{CKG}_{3}$ & 15.4 & 15.7 & 16.2 & 16.6 & 7.23 & $15.97 \mathrm{~b}$ \\
\hline $\mathrm{CKG}_{4}$ & 15.6 & 15.9 & 16.5 & 16.9 & 7.69 & $16.22 \mathrm{a}$ \\
\hline $\mathrm{CKG}_{5}$ & 15.3 & 15.8 & 16.2 & 16.6 & 7.83 & $15.97 b$ \\
\hline $\mathrm{CKG}_{6}$ & 15.4 & 15.7 & 15.9 & 16.3 & 5.52 & $15.82 \mathrm{c}$ \\
\hline Means & $15.47 d$ & $15.84 c$ & $16.30 \mathrm{~b}$ & $16.72 a$ & & \\
\hline
\end{tabular}

Figures having different small letters shows significant difference $(p<0.05)$

Table 3: Effect of ginger extract on the TSS (OBrix) of carrot and kinnow ready to serve beverage.

Similarly, decreased was observed in $\mathrm{pH}$ of ginger and kinnow squash during storage. The $\mathrm{pH}$ has got importance to maintain shelf stability and it can also influence the flavor of ready to serve beverage [6].

\section{Total soluble solids (TSS)}

The impact of storage and treatments on Total soluble solids TSS of value added ready to serve drinks prepared from blend of carrot, kinnow and ginger stored at refrigeration temperature presented in Table 3. Statistically both storage and treatments had significant $(\mathrm{p}<0.05)$ effect on TSS of ready to serve drinks. This is observed from the data that TSS of the treated sample were in range of $15.3\left(\mathrm{CKG}_{5}\right)$ to $15.6\left(\mathrm{CKG}_{2}\right.$ and $\left.\mathrm{CKG}_{4}\right)$ on zero day of storage, which increase up to $16.3\left(\mathrm{CKG}_{6}\right)$ to $17\left(\mathrm{CKG}_{2}\right)$ after 90 days of storage. Highest mean TSS (3.83) was observed for treatment $\mathrm{CKG}_{4}$, while the lowest mean TSS (3.56) was observed for control sample. In term of storage maximum mean TSS (16.72) was noticed at 90 day of storage, while minimum mean TSS (15.47) was recorded at day first of storage prepared RTS. However higher TSS increase was found in sample $\mathrm{CGG}_{0}(8.82 \%)$ while lower TSS was observed in $\mathrm{CKG}_{6}$ (5.52\%). Polysaccharides conversion into sugars during hydrolysis processes might be the reason for increase in TSS. Similarly, Sarolia and Mukherjee, Mehta and Bajaj, Bhardwaj and Mukherjee [7] reported that TSS increased during processing and storage of mandarin juice. This might be due to ginger juice inhibit microbial growth and subsequently reducing metabolic rate.

\section{Acidity}

Table 4 shows the impact of storage and treatments on acidity of value added ready to serve drinks made from blend of carrot, kinnow and ginger. Statistically both storage and treatments had significant $(\mathrm{p}<0.05)$ effect on acidity of ready to serve drinks. Similarly to TSS, acidity of prepared treated RTS drinks was increased during three months of storage from $0.45-0.5 \% \mathrm{CKG}_{4}$ and $\mathrm{CKG}_{3}$ to $0.59 \% \mathrm{CKG}_{5}$ 


\begin{tabular}{|c|c|c|c|c|c|c|}
\hline \multirow[t]{2}{*}{ Treatment } & \multicolumn{4}{|c|}{ Storage Intervals } & \multirow[t]{2}{*}{$\%$ decrease } & \multirow[t]{2}{*}{ Means } \\
\hline & 0 & 30 & 60 & 90 & & \\
\hline $\mathrm{CKG}_{0}$ & 0.47 & 0.52 & 0.58 & 0.63 & 25.40 & $0.55 c$ \\
\hline $\mathrm{CKG}_{1}$ & 0.47 & 0.52 & 0.57 & 0.62 & 24.19 & $0.54 \mathrm{c}$ \\
\hline $\mathrm{CKG}_{2}$ & 0.48 & 0.53 & 0.59 & 0.64 & 25.00 & $0.56 b$ \\
\hline $\mathrm{CKG}_{3}$ & 0.5 & 0.55 & 0.61 & 0.65 & 23.08 & $0.57 a$ \\
\hline $\mathrm{CKG}_{4}$ & 0.45 & 0.49 & 0.55 & 0.59 & 23.73 & $0.52 d$ \\
\hline $\mathrm{CKG}_{5}$ & 0.49 & 0.55 & 0.6 & 0.65 & 24.62 & $0.57 a$ \\
\hline $\mathrm{CKG}_{6}$ & 0.46 & 0.5 & 0.55 & 0.59 & 22.03 & $0.52 d$ \\
\hline Means & $0.47 d$ & $0.52 c$ & $0.57 b$ & $0.62 a$ & & \\
\hline
\end{tabular}

Figures having different small letters shows significant difference $(p<0.05)$

Table 4: Effect of ginger extract on the acidity of carrot and kinnow ready to serve beverage.

\begin{tabular}{|l|c|c|c|c|c|c|}
\hline \multirow{2}{*}{ Treatment } & \multicolumn{4}{|c|}{ Storage Intervals } & \multirow{2}{*}{ \% decrease } & Means \\
\cline { 2 - 5 } & 0 & 30 & 60 & 90 & & \\
\hline $\mathrm{CKG}_{0}$ & 32.29 & 30 & 27.79 & 26.25 & 18.71 & $29.08 \mathrm{c}$ \\
\hline $\mathrm{CKG}_{1}$ & 32.76 & 30.19 & 28.42 & 26.77 & 18.28 & $29.53 \mathrm{~b}$ \\
\hline $\mathrm{CKG}_{2}$ & 32.97 & 30.57 & 28.27 & 26.82 & 18.65 & $29.65 \mathrm{~b}$ \\
\hline $\mathrm{CKG}_{3}$ & 34.66 & 32.44 & 30 & 28.64 & 17.37 & $31.43 \mathrm{a}$ \\
\hline $\mathrm{CKG}_{4}$ & 31.22 & 28.72 & 27 & 25.53 & 18.23 & $28.11 \mathrm{~d}$ \\
\hline $\mathrm{CKG}_{5}$ & 30.8 & 28.54 & 26.06 & 25.07 & 18.60 & $27.61 \mathrm{e}$ \\
\hline $\mathrm{CKG}_{6}$ & 33.69 & 32 & 30 & 28.81 & 14.49 & $31.12 \mathrm{a}$ \\
\hline Means & $32.62 \mathrm{a}$ & $30.35 \mathrm{~b}$ & $28.22 \mathrm{c}$ & $26.84 \mathrm{~d}$ & & \\
\hline
\end{tabular}

Figures having different small letters shows significant difference $(p<0.05)$

Table 5: Effect of ginger extract on the sugar acid ratio of carrot and kinnow ready to serve beverage.

and $\mathrm{CKG}_{6}$ respectively. Highest mean acidity $(0.57)$ was observed for treatment $\mathrm{CKG}_{3}$ and $\mathrm{CKG}_{5}$, while the lowest mean acidity (0.52) was observed at sample $\mathrm{CKG}_{4}$. In term of storage maximum mean acidity (0.62) was noticed at 90 day of storage, while minimum mean acidity (0.47) was recorded at day first of storage prepared RTS. However, higher increase in acidity was found in sample $\mathrm{CGG}_{0}(25.40 \%)$ while lower acidity was observed in $\mathrm{CKG}_{6}(23.03 \%)$. The results are similar to the previous study which showed increase in acidity during storage which might be effected by the presence of microorganisms and sugar degradation [7]. Conclusively, acidity is an important characteristic which effect on the flavor and overall acceptability of juice.

\section{Sugar acid ratio}

The effect of storage and treatments on sugar acid ratio of value added ready to serve drinks prepared from blend of carrot, kinniow and ginger stored at refrigeration temperature was presented at Table 5. Statistically both storage and treatments had significant $(\mathrm{p}<0.05)$ effect on acidity of ready to serve drinks. This was observed from the data that sugar acid ratio of the treated sample were in range of 30.8 $\left(\mathrm{CKG}_{5}\right)$ to $34.66\left(\mathrm{CKG}_{3}\right)$ on zero day of storage, which decrease up to $25.07\left(\mathrm{CKG}_{5}\right) 25.82\left(\mathrm{CKG}_{2}\right)$ during 90 days of storage. In sugar acid ratio highest mean (31.43) was observed for treatment $\mathrm{CKG}_{3}$, while the lowest mean sugar acid ratio (27.61) was observed for control sample. In term of storage maximum mean sugar acid ratio (32.62) was noticed at zero day of storage, while minimum mean sugar acid ratio (26.84) was recorded after 90 days of storage prepared RTS. However higher sugar acid ratio decrease was found in sample $\mathrm{CGG}_{0}(18.71 \%)$ while lower sugar acid ratio was observed in $\mathrm{CKG}_{6}(14.49 \%)$. The same result were found by Asad and Durrani [8] who concluded decreasing of sugar acid ratio during the storage of apple pulp.

\section{Reducing sugar}

Table 6 shows the effect of storage and treatments on reducing sugar of value added ready to serve drinks prepared from blend of carrot, kinnow and ginger. Statistically both storage and treatments had significant $(p<0.05)$ effect on reducing sugar of ready to serve drinks. This was observed from the data that reducing sugar of the treated sample were in range of $12.62\left(\mathrm{CKG}_{2}\right)$ to $15.58\left(\mathrm{CKG}_{2}\right)$ on zero day of storage, which decrease up to $12.9\left(\mathrm{CKG}_{0}\right)$ to $15.73\left(\mathrm{CKG}_{1}\right)$ after 90 days of storage. Highest mean reducing sugar (15.65) was observed for treatment $C K G_{1}$, while the lowest mean reducing sugar (12.68) was observed at $\mathrm{CKG}_{1}$. In term of storage maximum mean reducing sugar (14.10) was recorded after 90 days of storage, while minimum mean reducing sugar (13.96) was noticed at zero day storage prepared RTS. However, higher reducing sugar was found in sample CGG $_{0}(1.40 \%)$ while lower sugar acid ratio was observed in $\mathrm{CKG}_{6}(0.87 \%)$. The results are parallel to result of Babsky et al. [9], Pruthi et al., [10]; Tripathi et al., [11] Attri et al., [12] which studied raise in reducing sugar of juice in storage duration, which might be influenced by the conversion of non-reducing sugar (sucrose).

\section{Non reducing sugar}

The impact of storage and treatments on non-reducing sugar of value added ready to serve drinks prepared from blend of carrot, kinnow and ginger stored at refrigeration temperature was presented in Table 7. Statistically both storage and treatments had significant $(\mathrm{p}<0.05)$ effect on non-reducing sugar of ready to serve drinks. This was observed from the data that non reducing sugar of the treated sample were in range of $4.87\left(\mathrm{CKG}_{5}\right)$ to $7.79\left(\mathrm{CKG}_{4}\right)$ on zero day of storage, which decrease up to $4.75\left(\mathrm{CKG}_{5}\right)$ to $7.64\left(\mathrm{CKG}_{4}\right)$ after 90 days of storage. Highest mean non reducing sugar (7.71) was observed for treatment $\mathrm{CKG}_{4}$, while the lowest mean non reducing sugar (4.80) was observed at $\mathrm{CKG}_{0}$. In term of storage maximum mean non reducing sugar (6.12) noticed at zero day of storage, while minimum (5.98) mean non reducing sugar recorded after 90 days of storage prepared

\begin{tabular}{|c|c|c|c|c|c|c|}
\hline \multirow[t]{2}{*}{ Treatment } & \multicolumn{4}{|c|}{ Storage Intervals } & \multirow[t]{2}{*}{$\%$ decrease } & \multirow[t]{2}{*}{ Means } \\
\hline & 0 & 30 & 60 & 90 & & \\
\hline $\mathrm{CKG}_{0}$ & 12.72 & 12.8 & 12.84 & 12.9 & 1.40 & $12.81 f$ \\
\hline $\mathrm{CKG}_{1}$ & 15.58 & 15.63 & 15.68 & 15.73 & 0.95 & $15.65 a$ \\
\hline $\mathrm{CKG}_{2}$ & 12.62 & 12.66 & 12.71 & 12.75 & 1.02 & $12.68 \mathrm{~g}$ \\
\hline $\mathrm{CKG}_{3}$ & 14.55 & 14.58 & 14.63 & 14.68 & 0.89 & $14.61 \mathrm{c}$ \\
\hline $\mathrm{CKG}_{4}$ & 13.65 & 13.69 & 13.75 & 13.78 & 0.94 & $13.71 \mathrm{e}$ \\
\hline $\mathrm{CKG}_{5}$ & 13.81 & 13.86 & 13.91 & 13.95 & 1.00 & $13.88 d$ \\
\hline $\mathrm{CKG}_{6}$ & 14.78 & 14.83 & 14.87 & 14.91 & 0.87 & $14.84 \mathrm{~b}$ \\
\hline Means & $13.96 d$ & $14.00 \mathrm{c}$ & $14.05 b$ & $14.10 \mathrm{a}$ & & \\
\hline
\end{tabular}

Figures having different small letters shows significant difference $(p<0.05)$ Table 6: Effect of ginger extract on the reducing of carrot and kinnow ready to serve beverage.

\begin{tabular}{|l|c|c|c|c|c|c|}
\hline \multirow{2}{*}{ Treatment } & \multicolumn{4}{|c|}{ Storage Intervals } & \% decrease & Means \\
\cline { 2 - 6 } & 0 & 30 & 60 & 90 & & \\
\hline $\mathrm{CKG}_{0}$ & 4.88 & 4.83 & 4.77 & 4.73 & 3.07 & $4.80 \mathrm{f}$ \\
\hline $\mathrm{CKG}_{1}$ & 5.78 & 5.73 & 5.68 & 5.65 & 2.25 & $5.71 \mathrm{~d}$ \\
\hline $\mathrm{CKG}_{2}$ & 5.66 & 5.61 & 5.57 & 5.51 & 2.65 & $5.58 \mathrm{e}$ \\
\hline $\mathrm{CKG}_{3}$ & 6.9 & 6.86 & 6.83 & 6.77 & 1.88 & $6.84 \mathrm{c}$ \\
\hline $\mathrm{CKG}_{4}$ & 7.79 & 7.74 & 7.68 & 7.64 & 1.93 & $7.71 \mathrm{a}$ \\
\hline $\mathrm{CKG}_{5}$ & 4.87 & 4.84 & 4.78 & 4.75 & 2.46 & $4.81 \mathrm{f}$ \\
\hline $\mathrm{CKG}_{6}$ & 6.97 & 6.93 & 6.88 & 6.85 & 1.72 & $6.90 \mathrm{~b}$ \\
\hline Means & $6.12 \mathrm{a}$ & $6.07 \mathrm{~b}$ & $6.02 \mathrm{c}$ & $5.98 \mathrm{~d}$ & & \\
\hline
\end{tabular}

Figures having different small letters shows significant difference $(p<0.05)$

Table 7: Effect of ginger extract on the non reducing sugar of carrot and kinnow ready to serve beverage. 
RTS. However higher non reducing sugar was found in sample $\mathrm{CGG}_{0}$ (3.07\%) while lower non reducing sugar was observed in $\mathrm{CKG}_{6}(1.72 \%)$. Pruthi et al., [10] suggested that the decrease in non-reducing sugar might be due to conversion of non-reducing sugar into reducing sugar during their study on Kinnow and Malta juice. Similar decline in nonreducing sugar were also observed in sugar contents, of pasteurized yellow passion fruit juice during storage during his study.

\section{Vitamin C}

Table 8 shows the effect of storage and treatments on vitamin $\mathrm{C}$ of value added ready to serve drinks prepared from blend of carrot, kinnow and ginger. Statistically both storage and treatments had significant $(\mathrm{p}<0.05)$ effect on vitamin $\mathrm{C}$ of ready to serve drinks. Differences in ascorbic acid contents were noticed in various treatments. This was observed from the data that vitamin- $\mathrm{C}$ of the treated sample were in range of $25.23\left(\mathrm{CKG}_{0}\right)$ to $28.34\left(\mathrm{CKG}_{5}\right)$ on zero day of storage, which decreased to $25.09\left(\mathrm{CKG}_{0}\right)$ to $27.19\left(\mathrm{CKG}_{5}\right)$ after 90 days of storage. Highest mean vitamin $C$ (28.26) was observed for treatment $\mathrm{CKG}_{5}$, while the lowest mean non vitamin $\mathrm{C}(25.15)$ was observed at $\mathrm{CKG}_{0}$. In term of storage maximum mean vitamin-C (26.84) noticed at zero day of storage, while minimum (26.70) mean vitamin-C recorded after 90 days of storage prepared RTS. However higher vitamin- $\mathrm{C}$ was found in sample CGG $\mathrm{CG}_{0}(0.55 \%)$ while lower vitamin $\mathrm{C}$ was observed in $\mathrm{CKG}_{6}(0.45 \%)$. Decline trend in ascorbic acid contents was reported during changes in Aonla pulp under different storage conditions [13]. Ascorbic acid content in orange squashes reduced dueto exposure to light. The degradation of vitamin C in RTS may pursue anaerobic and aerobic pathways [14].

\section{Taste}

Table 9 shows the effect of storage and treatments on taste of value added ready to serve drinks prepared from blend of carrot, kinnow

\begin{tabular}{|l|c|c|c|c|c|c|}
\hline \multirow{2}{*}{ Treatment } & \multicolumn{4}{|c|}{ Storage Intervals } & \% decrease & Means \\
\cline { 2 - 6 } & 0 & 30 & 60 & 90 & & \\
\hline $\mathrm{CKG}_{0}$ & 25.23 & 25.18 & 25.13 & 25.09 & 0.55 & $25.15 \mathrm{~g}$ \\
\hline $\mathrm{CKG}_{1}$ & 26.88 & 26.83 & 26.79 & 26.74 & 0.52 & $26.81 \mathrm{~d}$ \\
\hline $\mathrm{CKG}_{2}$ & 27.58 & 27.53 & 27.49 & 27.43 & 0.54 & $27.50 \mathrm{~b}$ \\
\hline $\mathrm{CKG}_{3}$ & 25.99 & 25.96 & 25.91 & 25.87 & 0.46 & $25.93 \mathrm{f}$ \\
\hline $\mathrm{CKG}_{4}$ & 27.22 & 27.18 & 27.13 & 27.08 & 0.51 & $27.15 \mathrm{c}$ \\
\hline $\mathrm{CKG}_{5}$ & 28.34 & 28.29 & 28.24 & 28.19 & 0.53 & $28.26 \mathrm{a}$ \\
\hline $\mathrm{CKG}_{6}$ & 26.66 & 26.61 & 26.57 & 26.54 & 0.45 & $26.59 \mathrm{e}$ \\
\hline Means & $26.84 \mathrm{a}$ & $26.79 \mathrm{~b}$ & $26.75 \mathrm{c}$ & $26.70 \mathrm{~d}$ & & \\
\hline
\end{tabular}

Figures having different small letters shows significant difference $(p<0.05)$ Table 8: Effect of ginger extract on the vitamin-c of carrot and kinnow ready to serve beverage.

\begin{tabular}{|c|c|c|c|c|c|c|}
\hline \multirow[t]{2}{*}{ Treatment } & \multicolumn{4}{|c|}{ Storage Intervals } & \multirow[t]{2}{*}{$\%$ decrease } & \multirow[t]{2}{*}{ Means } \\
\hline & 0 & 30 & 60 & 90 & & \\
\hline $\mathrm{CKG}_{0}$ & 8.3 & 7.8 & 7.3 & 6.7 & 19.28 & $7.52 d$ \\
\hline $\mathrm{CKG}_{1}$ & 8.4 & 7.9 & 7.4 & 7 & 16.67 & $7.67 \mathrm{~cd}$ \\
\hline $\mathrm{CKG}_{2}$ & 8.2 & 7.7 & 7.4 & 6.9 & 15.85 & $7.55 d$ \\
\hline $\mathrm{CKG}_{3}$ & 8.6 & 8.4 & 8.1 & 7.9 & 8.14 & $8.25 a$ \\
\hline $\mathrm{CKG}_{4}$ & 8.4 & 8 & 7.5 & 7.1 & 15.48 & $7.75 b$ \\
\hline $\mathrm{CKG}_{5}$ & 8 & 7.6 & 7.1 & 6.5 & 18.75 & $7.30 \mathrm{e}$ \\
\hline $\mathrm{CKG}_{6}$ & 8.5 & 8.2 & 7.8 & 7.3 & 14.12 & $7.95 b$ \\
\hline Means & 8.34a & $7.94 b$ & $7.51 \mathrm{c}$ & $7.05 d$ & & \\
\hline
\end{tabular}

Figures having different small letters shows significant difference $(p<0.05)$

Table 9: Effect of ginger extract on the taste of carrot and kinnow ready to serve beverage.

\begin{tabular}{|c|c|c|c|c|c|c|}
\hline \multirow[t]{2}{*}{ Treatment } & \multicolumn{4}{|c|}{ Storage Intervals } & \multirow[t]{2}{*}{$\%$ decrease } & \multirow[t]{2}{*}{ Means } \\
\hline & 0 & 30 & 60 & 90 & & \\
\hline $\mathrm{CKG}_{0}$ & 8.3 & 7.9 & 7.4 & 6 & 27.71 & $7.40 \mathrm{~d}$ \\
\hline $\mathrm{CKG}_{1}$ & 8.4 & 8 & 7.7 & 7.3 & 13.10 & $7.85 \mathrm{bc}$ \\
\hline $\mathrm{CKG}_{2}$ & 8.1 & 7.7 & 7.3 & 7 & 13.58 & $7.52 \mathrm{~cd}$ \\
\hline $\mathrm{CKG}_{3}$ & 8.5 & 8.3 & 8 & 7.7 & 9.41 & $8.12 a b$ \\
\hline $\mathrm{CKG}_{4}$ & 8.4 & 8.1 & 7.9 & 7.5 & 10.71 & 7.97ab \\
\hline $\mathrm{CKG}_{5}$ & 8.2 & 7.8 & 7.3 & 6.8 & 17.07 & $7.52 \mathrm{~cd}$ \\
\hline $\mathrm{CKG}_{6}$ & 8.6 & 8.4 & 8.1 & 7.9 & 8.14 & $8.25 a$ \\
\hline Means & $8.35 a$ & $8.02 b$ & $7.67 c$ & $7.17 d$ & & \\
\hline
\end{tabular}

Figures having different small letters shows significant difference $(p<0.05)$

Table 10: Effect of ginger extract on the color of carrot and kinnow ready to serve beverage.

and ginger. Statistically both storage and treatments had significant $(p<0.05)$ effect on taste of ready to serve drinks. Taste is very important factor in organoleptic evaluation after color and texture. This was observed from the data that taste of the treated sample were in range of $8\left(\mathrm{CKG}_{5}\right)$ to $8.6\left(\mathrm{CKG}_{3}\right)$ on zero day of storage, which decrease up to $6.5\left(\mathrm{CKG}_{5}\right)$ to $7.9\left(\mathrm{CKG}_{3}\right)$ after 90 days of storage. Highest mean taste (8.25) was observed for treatment $\mathrm{CKG}_{3}$, while the lowest mean taste (7.30) was observed at $\mathrm{CKG}_{5}$. In term of storage maximum mean taste (8.34) noticed at zero day of storage, while minimum (7.05) mean taste recorded after 90 days of storage prepared RTS. However higher taste was found in sample CGG $_{0}(19.28 \%)$ while lower taste was observed in $\mathrm{CKG}_{3}(8.14 \%)$. Loss in the taste of kinnow anola juice was reported due to changes in volatile compounds throughout storage [15]. The difference in taste might be due to in stored products. Similarly, loss in taste of juice was observed by Jain and Khurdiya, Jain et al., [16] during their study on physiochemical and sensory properties of orange drink.

\section{Color}

The effect of storage and treatments on color of value added ready to serve drinks prepared from blend of carrot, kinnow and ginger stored at refrigeration temperature was presented in Table 10. Statistically both storage and treatments had significant $(\mathrm{p}<0.05)$ effect on color of ready to serve drinks. This was observed from the data that color of the treated sample were in the range of $8.1\left(\mathrm{CKG}_{2}\right)$ to $8.6\left(\mathrm{CKG}_{6}\right)$ on zero day of storage, which decreases up to (6) at $\mathrm{CKG}_{0}$ to (6.8) at $\mathrm{CKG}_{5}$ after 90 days of storage. Highest mean color (8.25) was observed for treatment $\mathrm{CKG}_{6}$, while the lowest mean color (7.40) was observed at $\mathrm{CKG}_{0}$. In term of storage maximum mean color (8.35) was recorded after at first day of storage, while minimum mean color (7.17) was noticed at 90 days storage prepared RTS. However higher decrease in color was found in sample CGG $(27.71 \%)$ while lower decrease in color was observed in $\mathrm{CKG}_{6}(8.14 \%)$. Millard reaction was accelerated throughout storage which resulted in loss of color of carrot and kinnow RTS. Loss of color in beverage during storage of 2-Methyl3 -furanthiol and methanol are possible off-flavors in stored orange juice were [17]. Ascorbic acid retention in orange squashes as related to exposure to light and container types well as action of acids present in RTS beverage.

\section{Flavor}

Table 11 shows the effect of storage and treatments on flavor of value added ready to serve drinks prepared from blend of carrot, kinnow and ginger. Statistically both storage and treatments had significant $(\mathrm{p}<0.05)$ effect on flavor of ready to serve drinks. This was observed from the data that flavor of the treated sample were in range of $8.1\left(\mathrm{CKG}_{4}\right)$ to $8.5\left(\mathrm{CKG}_{3}\right)$ on zero day of storage, which decrease up to $6.7\left(\mathrm{CKG}_{0}\right)$ to $7.7\left(\mathrm{CKG}_{3}\right)$ after 90 days of storage. Highest mean 
Citation: Ullah N, Qazi IM, Masroor S, Ali I, Khan A, et al. (2015) Preservation of Ready to Serve Blended Carrot and Kinnow (Mandarin) Drink by Ginger Extract. J Food Process Technol 6: 438. doi:10.4172/2157-7110.1000438

Page 5 of 6

\begin{tabular}{|c|c|c|c|c|c|c|}
\hline \multirow[t]{2}{*}{ Treatment } & \multicolumn{4}{|c|}{ Storage Intervals } & \multirow[t]{2}{*}{$\%$ decrease } & \multirow[t]{2}{*}{ Means } \\
\hline & 0 & 30 & 60 & 90 & & \\
\hline $\mathrm{CKG}_{0}$ & 8.2 & 7.8 & 7.3 & 6.7 & 18.29 & $7.50 \mathrm{~d}$ \\
\hline $\mathrm{CKG}_{1}$ & 8.3 & 7.9 & 7.5 & 7 & 15.66 & $7.67 \mathrm{~cd}$ \\
\hline $\mathrm{CKG}_{2}$ & 8.4 & 8.1 & 7.7 & 7.2 & 14.29 & $7.85 \mathrm{bc}$ \\
\hline $\mathrm{CKG}_{3}$ & 8.5 & 8.3 & 8 & 7.7 & 9.41 & $8.12 a$ \\
\hline $\mathrm{CKG}_{4}$ & 8.1 & 7.7 & 7.4 & 7 & 13.58 & $7.55 d$ \\
\hline $\mathrm{CKG}_{5}$ & 8.3 & 7.7 & 7.3 & 6.8 & 18.07 & $7.52 d$ \\
\hline $\mathrm{CKG}_{6}$ & 8.4 & 8.1 & 7.9 & 7.6 & 9.52 & $8.00 \mathrm{ab}$ \\
\hline Means & 8.31a & $7.94 b$ & $7.58 \mathrm{c}$ & $7.14 d$ & & \\
\hline
\end{tabular}

Figures having different small letters shows significant difference $(p<0.05)$

Table 11: Effect of ginger extract on the flavor of carrot and kinnow ready to serve beverage.

\begin{tabular}{|c|c|c|c|c|c|c|}
\hline \multirow[t]{2}{*}{ Treatment } & \multicolumn{4}{|c|}{ Storage Intervals } & \multirow[t]{2}{*}{$\%$ decrease } & \multirow[t]{2}{*}{ Means } \\
\hline & 0 & 30 & 60 & 90 & & \\
\hline $\mathrm{CKG}_{0}$ & 8.1 & 7.7 & 7.4 & 6 & 25.93 & $7.30 \mathrm{c}$ \\
\hline $\mathrm{CKG}_{1}$ & 8.3 & 7.9 & 7.6 & 7.2 & 13.25 & $7.75 b$ \\
\hline $\mathrm{CKG}_{2}$ & 8.2 & 7.9 & 7.5 & 7.1 & 13.41 & $7.67 b$ \\
\hline $\mathrm{CKG}_{3}$ & 8.3 & 8 & 7.6 & 7.3 & 12.05 & $7.80 \mathrm{~b}$ \\
\hline $\mathrm{CKG}_{4}$ & 8.1 & 7.8 & 7.4 & 7.1 & 12.35 & $7.60 \mathrm{~b}$ \\
\hline $\mathrm{CKG}_{5}$ & 8.4 & 8.1 & 7.7 & 7.2 & 14.29 & $7.85 a b$ \\
\hline $\mathrm{CKG}_{6}$ & 8.5 & 8.3 & 8 & 7.6 & 10.59 & $8.10 a$ \\
\hline Means & $8.27 a$ & $7.95 b$ & $7.60 \mathrm{c}$ & $7.07 d$ & & \\
\hline
\end{tabular}

Figures having different small letters shows significant difference $(p<0.05)$

Table 12: Effect of ginger extract on the overall acceptability of carrot and kinnow ready to serve beverage.

flavor (8.12) was observed for treatment $\mathrm{CKG}_{3}$, while the lowest mean flavor (6.7) was observed at $\mathrm{CKG}_{5}$. In term of storage maximum mean flavor (8.31) noticed at zero day of storage, while minimum (7.14) mean taste recorded after 90 days of storage prepared RTS. However higher flavor was found in sample CGG CG $_{0}(18.29 \%)$ while lower flavor was observed in $\mathrm{CKG}_{3}(9.41 \%)$. Off flavour was reported due to changes in volatile compounds of kinnow anola beverages. The difference in flavor might be due to storage conditions and storage time. Similar observation during research on physiochemical and sensory properties of orange drink were also noticed by Jain et al., [16]. A decrease in flavor during storage study on 2-Methyl-3-furanthiol and methional in stored orange juice of beverage was also reported by Bezman [17].

\section{Overall acceptability}

The impact of storage and treatments on overall acceptability of value added ready to serve drinks prepared from blend of carrot, kinnow and ginger stored at refrigeration temperature was presented in Table 12. Statistically both storage and treatments had significant $(p<0.05)$ effect on overall acceptability of ready to serve drinks. This was observed from the data that Overall acceptability of the treated sample were in the range of $8.1\left(\mathrm{CKG}_{0}\right.$ and $\left.\mathrm{CKG}_{4}\right)$ to $8.5\left(\mathrm{CKG}_{6}\right)$ on zero day of storage, which decreases up to (6) at $\mathrm{CKG}_{0}$ to (7.6) at $\mathrm{CKG}_{6}$ after 90 days of storage. Highest mean over all acceptability (8.10) was observed for treatment $\mathrm{CKG}_{6}$, while the lowest mean overall acceptability (7.30) was observed at $\mathrm{CKG}_{0}$. In term of storage maximum mean overall acceptability (8.27) noticed at zero day of storage, while minimum (7.07) mean overall acceptability recorded after 90 days of storage prepared RTS. However higher overall acceptability was found in sample $\mathrm{CGG}_{0}(25.93 \%)$ while lower overall acceptability was observed in $\mathrm{CKG}_{6}(10.59 \%)$. These results are in agreement with result showed by Rosario [18], who observed decline in overall acceptability is due to increase in storage interval which leads to progressive degradation.

Loss of overall acceptability in orange juice might be due to processing conditions like, temperature and storage time.

\section{Conclusion and Recommendation}

Carrot and kinnow RTS was prepared in this research, Study concluded that the ginger can be effectively used in different proportions as natural antioxidant and alternative source of chemical preservatives for inhibition of microbial growth in carrot and kinnow RTS. Ready to serve beverage was packed in glass bottles, stored at -refrigeration temperature and for three months. The products were studied for physic-chemical and sensory evaluations at the interval of 30 days. On the basis of result obtained it is concluded that treatments $\mathrm{CKG}_{6}$ and $\mathrm{CKG}_{3}$ were best treatments having best keeping quality during storage and can be used in commercialization of carrot and kinnow RTS. Some changes were noticed in physiochemical characteristics but these changes did not influence the product considerably. The sensory parameters decrease slightly but remains in acceptable range during storage period.

\section{Recommendations}

- Further research work should be done on various proportions of ginger.

- The present research work was conducted at refrigeration temperature, so this research work should also be carried out in other storage conditions.

- Same proportions of ginger can also be used in other RTS beverages.

Other natural anti oxidant can also be used in carrot and kinnow RTS.

\section{References}

1. Muhammad R, Ahmed M, Chaudhry MA, Hussain B, Khan I (1987) Ascorbic acid quality retention in orange squashes as related to exposure to light and container type. J Pak Scilnd Res 30: 480-483.

2. AOAC (Association of official and analytical chemist) (2012) Arlington, Virgina USA.

3. Larmond E (1985) Lab methods of sensory evaluation of food. Pub. Canada, Canada.

4. Kumar KA, Ramaswamy L, Rajendran R, Sundaram SK (2011) Preparation and microbial evaluation of RTS beverage (pun;ch) prepared with lactic acid fermented carrots and sweet lime juice. J Food sci 34: 2461-2464.

5. Steel RGD, Torrie JH (1997) Principles and procedures of statistics with special refrence to the biological sciences. J Biometr 4: 207-208.

6. Vikram B, Prasad MV (2014) Studies on Value Added Kinnow-Aonla Blended Ready to Serve Beverage. J Food Process Technol 5: 1.

7. Bhardwaj RL, Pandey S (2011) Juice blends-A way of utilization of underUtilized fruits, vegetables, and spices: a review. Critical Reviews in Food Science and Nutrition 51: 563-570.

8. Asad A, Durrani Y (2009) Physicochemical response of apple pulp to chemical preservative during storage. Agri Univ Peshawar.

9. Babsky JE, Toribio JL, Lozano JE (1986) Influence of storage on the composition of clarified apple juice concentrate. J. Food Sci 51: 564-567.

10. Pruthi JS, Manan JK, Teotia MS, Podhakri-Shnasetty G, Epison WE, et al (1984) Studies on the utilization of Kinnow and Malta. J Food Sci Tech 21: 123-127.

11. Tripathi VK, Lyndgohand K, Singh S (1992) Studies on blending of pineapple juice with different ratio of guava juice for preparation of RTS beverage. Prog Hort 24: 60-65.

12. Attri BL, Lal BB, Joshi VK (1998) Physico-chemical characteristics,sensory quality and storage behavior of sand pear juice blended withtemperate fruit juice/pulps. Indian Food Packer 52: 36-38. 
Citation: Ullah N, Qazi IM, Masroor S, Ali I, Khan A, et al. (2015) Preservation of Ready to Serve Blended Carrot and Kinnow (Mandarin) Drink by Ginger Extract. J Food Process Technol 6: 438. doi:10.4172/2157-7110.1000438

Page 6 of 6

13. Ranote PS, Bains GS (1982) Juice of Kinnow fruits. Indian Food Packer 36: 23-33.

14. Moshonas MG, Shaw PE (1989) Changes in composition of volatile components in aseptically packed orange juice during storage. J Agric Food Chem 37: 157-161.

15. Marcy JE, Graumlich TR, Grandallands PG, Marshall MR (1984) Factors affecting storage of orange concentrate. J Food Sci 49: 1628-1629.
16. Jain S, Sankhla APK, Dashora A, Sankhla AK (2003) Physiochemical and sensory properties of orange drink. J Food Sci Tech India 40: 656-659.

17. BezmanY, Russell RL, Naim M (2001) 2-Methyl-3-furanthiol and methional are possible off-flavors in stored orange juice. J Agric Food Chem 49: 5425-5432.

18. Rosario MJG (1996) Formulation of ready to drink blends from fruits and vegetables juices. J Philippines 9: 201-209. 